\title{
MUZYKA W KULTURZE CHIŃSKIEJ
}

\author{
MUSIC IN CHINESE CULTURE
}

\begin{abstract}
A bstract. Summing up the development of Chinese music, we cannot forget, that Chinese music still remains very individual and characteristic in spite of the west having its influence on it. We are dealing with a very different musical culture, especially having taken the development of ancient music.

From the start music in China played a major role, it was closely bonded with philosophy and religion. The belief in social and educational effects of music contributed to surrounding it with cult. Typical restraints, applied to only a few genres, interpretations and instruments and its rigorous conservatism and archaic nature made this music exceptional and one of a kind. For ancient Chinese culture music became the wisdom of the heart, which was and continues to be a hardwired part of every Chinese person's life.
\end{abstract}

Chiny to obszar, który od tysiącleci był kolebką wielu kultur - chińskiej, tybetańskiej, japońskiej, koreańskiej, w których muzyka była szczególnie wysoko ceniona i silnie związana z kultem. Na Dalekim Wschodzie od wieków prowadzono politykę izolacjonistyczną. Chiny szczególnie ostro przeciwstawiały się kontaktom z narodami zamieszkującymi na zachód, a zwłaszcza na północ, od których odgrodziły się Wielkim Murem Chińskim. Kultura muzyczna Chin należy do najstarszych, bardzo specyficznych, a przy tym silnie oddziałujących kultur Azji. Początki kultury chińskiej, poświadczone przez źródła (wykopaliska z Anyangu), sięgają połowy II tysiąclecia p.n.e. $\mathrm{Na}$ postawie badań instrumentów muzycznych, ich cech stylistycznych oraz materiału, z którego zostały wykonane, przypuszcza się jednak, że kultura muzyczna Chin jest znacznie starsza. Charakterystyczną cechą tej kultury jest ciagłość tradycji, niespotykana w innych kulturach.

DiANA WolAŃSKA - doktorantka Katedry Sinologii Katolickiego Uniwersytetu Lubelskiego Jana Pawła II; adres do korespondencji - e-mail: alanis7@wp.pl 
Wyjątkowa odrębność muzyki chińskiej wynika w znacznym stopniu ze związku muzyki starożytnych Chin z religią i filozofią: narzuciły one muzyce niezmienne normy, miary, zakazy i nakazy, których należało rygorystycznie przestrzegać. Poprzez podobną postawę wobec muzyki wyraża się w sposób najbardziej uderzający wzajemny związek między umysłowością chińską a grecką. Platon w IV wieku p.n.e. sugerował, że muzyka powinna być jednym z podstawowych czynników greckiego wykształcenia, gdyż kształtuje duszę i charakter, dobra muzyka daje rękojmię istnienia należycie zorganizowanej społeczności, podczas gdy zła muzyka spycha państwo ku niebezpieczeństwom ${ }^{1}$. Dla społeczności podstawową sprawą byłby więc nadzór państwowy nad muzyką i obowiązkowe jej nauczanie.

Identyczną doktrynę ponad sto lat wcześniej od filozofa greckiego głosił chiński mędrzec Konfucjusz (551-479 p.n.e.). Podczas swoich podróży po różnych regionach Chin potrafił przez muzykę danego regionu wnioskować o jakości rządów danej prowincji. W czasie tych podróży zebrał wiele tekstów rozmaitych pieśni. Uważał, że odpowiednia muzyka wyraża harmonię między niebem a ziemią, przez co łagodzi konflikty między warstwami społecznymi oraz harmonizuje społeczeństwo. „Gdy kotły i bębny zagrzmią jak grzmot, rozlegną się dźwięki talerzy i litofonów jak piorun; gdy dźwięki fletów i skrzypiec, tańca i śpiewu ogłuszą hałasem słuchających - wszystko to może poruszyć nerwy, podniecić zmysły i wzburzyć życie. Lecz muzyka działająca takimi środkami nie rozporządza. Dlatego im huczniejsza muzyka, tym bardziej melancholijni są ludzie, tym niebezpieczniejszy staje się kraj i tym niżej upada władca. W ten sposób zatraca się również istota muzyki"2.

Wykształcenie muzyczne wysoko urodzonych Chińczyków dyktowane było nie tyle zróżnicowaniem społecznym, ile zapotrzebowaniem na ludzi o zrównoważonej osobowości. Konfucjusz powiadał: „Ody pobudzają pamięć. Dzięki Zasadom Stosowności umacnia się charakter. Z muzyki wywodzi się pojmowanie końca" ${ }^{\text {. }}$.

Znaczenie muzyki jasno określa system konfucjański, uznając ją za jedną z głównych sił regulujących porządek wszechświata. Muzyka, będąc jednym z przejawów wielkiej jedności kosmosu, podlegała określonym prawom za-

\footnotetext{
${ }^{1}$ Por. CURT SACHS, Historia instrumentów muzycznych, Kraków: Polskie Wydawnictwo Muzyczne, 1989, s. 142.

${ }^{2}$ Z Wiosen i Jesieni Lü Buwei'a, tł. Richarda Wilhelma. Cyt. za: Wolfram EBerhard, Symbole chińskie. Slownik. Obrazkowy język Chińczyków, tł. RENATA DARDA, Kraków: TAiWPN UNIVERSITAS, 2001, s. 164.

${ }^{3}$ Cyt. za: SACHS, Historia instrumentów muzycznych, s. 142.
} 
leżności i połączeń z jego innym elementami. Znajomość i przestrzeganie tych praw miało gwarantować zachowanie ładu w społeczeństwie i całym świecie otaczającym człowieka.

Ogromne znaczenie muzyki wynikało z faktu, że mogła ona pozostawać pod kontrolą człowieka. Większość składników wszechświata - przestrzeń, czas, substancje, siły - nie poddawała się woli człowieka, natomiast muzykę i jej podstawowe elementy, dźwięki, tworzył on sam. Stanowiła ona źródło wpływów człowieka na harmonię kosmosu. Tworzenie i słuchanie niewłaściwej muzyki, niezgodnej z prawami kosmosu, zagrażało bowiem nie tylko jednostce, uniemożliwiając jej osiągnięcie jedności z otaczającym ją światem, ale także bezpieczeństwu państwa, jego ładowi społecznemu.

Chińczycy więc wysoko oceniali możliwości muzyki w zakresie jej oddziaływania na życie człowieka. Odpowiednia muzyka pomagała $\mathrm{w}$ osiągnięciu równowagi i spokoju, a równocześnie była ważnym czynnikiem decydującym o porządku w społeczeństwie. Nic więc dziwnego, że sprawą niezwykle ważną, wręcz o randze państwowej, było poznawanie i przestrzeganie w procesie tworzenia muzyki niezwykle ścisłych, tradycyjnych norm, które odpowiadać miały prawom regulującym ład we wszechświecie.

Ta wyróżniająca pozycja muzyki przyczyniła się do otoczenia jej kultem, do przestrzegania tradycji i jej wielkiej zachowawczości. Pośrednim rezultatem stał się bardziej uniformistyczny charakter muzyki chińskiej. Jest on wynikiem tego, że w Chinach przez długie wieki uprawiano tylko niektóre gatunki, jak np. muzykę kultową, dworską, kameralną, przy wyraźnym ograniczeniu muzyki rozrywkowej, bardzo rozpowszechnionej w innych częściach Azji. Ograniczono się tylko do pewnych form wielogłosowości, do wybranych skal i określonego instrumentarium.

Muzyka w starożytnych Chinach zarówno towarzyszyła zabiegom magicznym, jak i była bardzo ważnym czynnikiem wychowania moralnego i społecznego. $Z$ jej uwarunkowań kosmologicznych wynikało przestrzeganie norm i miar wyrażonych za pomocą liczb uświęconych kultem - zwłaszcza $5,8,12$. Uznanie wychowawczego oddziaływania muzyki zapewniało jej trwałą pozycję na dworze cesarskim. Wszystkie te czynniki decydowały o ogromnej odpowiedzialności ciążącej zarówno na twórcy, jak i na wykonawcy muzyki. Konserwatyzm tej muzyki wynikał $\mathrm{z}$ obawy przed ewentualnością niepożądanych odchyleń od norm.

Bezpośrednie oddziaływania kultury chińskiej sięgały odległych regionów. Obejmowały one obszar od Turkiestanu i Mongolii na zachodzie i północy po Indonezję na południowym wschodzie i wyspy japońskie na wscho- 
dzie. Kontakty i związki kultury chińskiej z innymi kulturami są od dawna poświadczone przez źródła. Były one ściśle związane $\mathrm{z}$ rozrostem terytorialnym imperium chińskiego, zaznaczającym się zwłaszcza w końcowym okresie epoki starożytnej, a także z ruchami migracyjnymi narodów chińskich oraz sąsiadujących z nimi (Thai, Turków, Mongołów) na południe, zachód i północ. Kontakty z kulturami położonymi na południe i na zachód były szczególnie silne za dynastii Han, gdy kultury indoscytyjskie Gandary, dynastii Kuszanu, a następnie Turfanu i Kotanu, odgrywały rolę pośredniczącą między Dalekim a Bliskim Wschodem.

Związki te stały się szczególnie ewidentne w dziedzinie instrumentarium, w szczególności instrumentów strunowych szarpanych, zwłaszcza lutni. Najintensywniejszej sinizacji uległy jednak kraje bezpośrednio związane z Chinami, tj. Korea czy Japonia, lub też zamieszkałe przez narody, które przywędrowały z Chin - tu oczywiście przede wszystkim Wietnam. W krajach tych, niepozbawionych zresztą własnych tradycji regionalnych, do dziś zachowały się prastare elementy kultury chińskiej, w samych Chinach już niewystępujące, jak np. dawny typ orkiestry dworskiej w Korei Południowej czy orkiestry z epoki Tang w Japonii.

Dawna muzyka, z czasów pierwszych dynastii chińskich, poświadczona jest przez źródła archeologiczne (instrumenty: dzwony, okaryny, litofony), ikonograficzne oraz teksty utrwalone pismem obrazkowym na skorupach żółwi. Najstarsze poświadczenia źródłowe (nie archeologiczne) sięgają epoki Zhou. Są to wzmianki w Księdze pieśni zachodnich Zhou (1122-274 p.n.e.). Pozwalają one sobie wyobrazić istnienie instrumentu siedmiostrunowego. Według uczonych chińskich na tych instrumentach akompaniowano śpiewom podczas obrzędów konfucjańskich.

Muzyka w starożytnych Chinach odgrywała dużą rolę w wychowaniu potomstwa panujących rodów oraz w kulcie przodków. Już jednak sam Konfucjusz mówił o istnieniu muzyki „nowej”, niebezpiecznej, która sprzeniewierzała się surowym zasadom pentatoniki, wprowadzając nowe tony pozapentatoniczne. Muzykę tę wzmiankowano już w IV wieku p.n.e. Zanikła ona niemal całkowicie na fali pogromu, kiedy doszło do spalenia ksiąg w 213 p.n.e., co spowodowało, że ciągłość tradycji została w znacznym stopniu zniweczona. Poszczególne jednak elementy tej „nowej” muzyki, jak i muzyki dawnej (dworskiej i kultowej) przetrwały do następnych okresów ${ }^{4}$.

\footnotetext{
${ }^{4}$ Robert C. Provine, Yosiniko Tokumaru, and J. Lawrence Witzleben (eds), Garland Encyclopedia of World Music, vol. 7: East Asia: China, Japan, and Korea, University of Maryland, 2001, s. 206.
} 
Przełomowe znaczenie miał schyłek I tysiąclecia p.n.e. i początek nowego tysiąclecia. Doszło wówczas do upadku i zatarcia się tradycyjnej klasycznej muzyki chińskiej, pewnego rodzaju przewartościowania jej walorów moralnych i estetycznych. Imperium chińskie zwolna rozrastało się wtedy terytorialnie, a co za tym idzie - było infiltrowane przez elementy kultur innych narodów (w szczególności mieszkających na południe od Chin).

Do dat niezmiernie ważnych w historii starożytnej muzyki chińskiej zalicza się IV wiek p.n.e., kiedy została ustalona skala pentatoniczna i nazwy jej stopni. Z młodszego okresu pochodzą poświadczenia skali siedmiostopniowej, natomiast wiek III ukazuje wzmianki o skali materiałowej dwunastostopniowej. Informacje z II wieku poświadczają istnienie skali materiałowej sześdziesięciostopniowej, obejmujących 60 kolejnych lü (kwint), z tym że skala nie miała nigdy charakteru chromatycznego. Wszystko to pozwala domyślać się istnienia $\mathrm{w}$ tych odległych czasach pisma nutowego, są to jednak dane wciąż bardzo nieprecyzyjne, nieścisłe, niepewne.

W starożytności muzyka miała charakter obrzędowy, a nawet magiczny. Trzeba tutaj wspomnieć, że muzyka, zapewniając dobrobyt i pomyślność państwa, musiała czerpać prawa z kosmosu. Dlatego też stanowiła nierozdzielną część harmonii ze wszechświatem. Kosmos był ucieleśnieniem wieczności czasu i jako taki łączył w sobie zmieniające się pory roku, wiosnę i lato, jesień i zimę. Kosmos był również wcieleniem odwiecznej przestrzeni, integrując to wszystko, co leżało na wschodzie i zachodzie, na północy i południu. Był również materią jednoczącą w sobie drewno i metal, skórę i kamień, był siłą ucieleśniającą wiatr, błyskawice, żywioły wody i ognia. Kosmos był również brzmieniem w obu jego pojęciach: jako wysokość dzwięku i jego barwa. Wszechświat jest jeden, za to czas, przestrzeń, materia i muzyka są konkurentne, jako że stanowią tylko rozmaite przejawy tej samej jedności. Konkurentne powinny być również gałęzie poszczególnych kategrii, np. pewne pory roku korespondują z pewnymi stronami świata, rodzajami materii i instrumentami muzycznymi. Cztery pory roku odziela od siebie nie tylko ich określone miejsce w czasie, lecz również interwalika muzyczna. Błędne połączenia zagroziłyby harmonii świata ${ }^{5}$.

W następstwie tej koncepcji świata nauka starożytnych Chin ugrzęzła we wszelkiego rodzaju koordynacjach. Chiński myśliciel Laozi, potępiając przy-

${ }^{5}$ DanUta SzlagowsKa, Kultura muzyczna antyku, Gdańsk: Wydawnictwo Akademii Muzycznej im. Stanisława Moniuszki, 1983, s. 18. 
jemność zmysłową, porównuje pięć dźwięków pentatoniki z barwami: czarną, czerwoną, białą zieloną i zółtą, i ze smakami: słonym, gorzkim, kwaśnym, kwaskowatym i słodkim.

„Pięć barw oczu widzenia pozbawi;

Pięć tonów może ucho głuchym uczynić;

Czucie ustom odbiera pięć smaków"6.

Najważniejsza koordynacja dotycząca muzyki, a obejmująca strony świata, pory roku, zjawiska, substancje i instrumenty muzyczne, nazywała się pa-in. W myśl tej koordynacji Chińczycy przejęli jedyną w swoim rodzaju klasyfikację instrumentów muzycznych, wyodrębniając osiem klas pod kątem materiału użytego do ich budowy. Były to więc instrumenty tykwowe, bambusowe, drewniane, jedwabne, gliniane, matalowe, kamienne oraz skórzane. Materiał instrumentu jest $\mathrm{w}$ muzyce Chin czymś o wiele ważniejszym niż tylko medium powodującym powstanie dźwięku. Materiał i jego brzmienie, podobnie jak ciało i dusza, są nierozłączne. Dźwięk jest prawie namacalny, a idiofon kamienny w chińskiej terminologii powinien przy zakończeniu każdego wersetu w hymnie do Konfucjusza „obierać ton”, by przekazać go następnemu.

W koncepcji Dalekiego Wschodu dźwięk nie musi mieć określonego czasu trwania ani rytmu, nie powinnien być przerywany ani też zastępowany innymi dźwiękami. Im dłużej trwa i im bardziej jest wyizolowany, tym bardziej słuchacze są wtajemniczeni w życie materii, która go wytworzyła.

W świetle tej koncepcji można zrozumieć odpowiednio ważne znaczenie idiofonów w chińskiej muzyce. Tylko jedna z ośmiu substancji była tworzywem dla instrumentów strunowych i jedna dla bębnów. Natomiast aerofony, jak i idiofony sporządzane były z trzech rodzajów materii. Idiofony odgrywały na Dalekim Wschodzie rolę bardziej zasadniczą niż w innych cywilizacjach. Dlatego też wiele wschodnioazjatyckich idiofonów rozwinęło się w instrumenty melodyczne, podczas gdy w cywilizacjach zachodnich ich funkcja ograniczała się niemal do roli instrumentu perkusyjnego.

Aby jednak idiofon mógł spełniać rolę instrumentu melodycznego, powinnien dysponować szeregiem dźwięków o różnych wysokościach. Uzyskiwano je w ten sposób, że łączono szeregi dzwonów, płyt metalowych lub kamiennych gongów w zestawy, składające się z elementów o różnych rozmiarach, lecz jednakowych kształtach. Właśnie te zestawy są jedną z głów-

\footnotetext{
${ }^{6}$ Cyt. za: SACHS, Historia instrumentów muzycznych, s. 143.
} 
nych cech muzyki Azji Wschodniej, żadna z innych cywilizacji nie stworzyła tego rodzaju instrumentów ${ }^{7}$.

Osiągnięcie dokładności stroju przy budowaniu idiofonu było znacznie trudniejsze niż przy konstruowaniu innych instrumentów. Wysokością stroju i skalą rządziły prawa kosmologiczne, a ich zgodność ze wszechświatem wiązała się z przejęciem miar muzycznych z kategorii niemuzycznych, tak jak kategorie niemuzyczne mierzono proporcjami muzycznymi. Oznaczło to, że interwały między porami roku można było mierzyć oktawami, kwintami, kwartami (są to odległości między dźwiękami), natomiast długość piszczałki strojeniowej wynosiła dokładnie jedną stopę (chińską). We flecie odległości między poszczególnymi otworami nie wyznaczały normy techniczne czy muzyczne, lecz po prostu jednostki miary długości - cale. Jak głosi jeden z mitów, jedną z pierwszych czynności nowych cesarzy było delegowanie własnego ministra na zachód $\mathrm{w}$ góry, aby ten przyniósł od ptaka feniksa właściwy strój.

W czasach już historycznych opiekę nad muzyką sprawował minister miar. Kiedy barbarzyńscy najeźdźcy zniszczyli instrumenty będące wzorcami, następne dynastie dokładały starań, by na nowo przywrócić skalę i wysokość stroju, wierząc, że w ten sposób zbawiają świat. Dlatego też Mencjusz powiedział: „W materii dźwięków według nauczyciela muzyki Kuanga odwzorowuje się całe państwo"8. Ten cytat również pokazuje, jaki wpływ miała muzyka na społeczństwo i harmonię w państwie.

Aby poznać muzykę Chin, musimy zagłębić się w historię, odkrywając krok po kroku, co tworzyły w tej dziedzinie poszczególne dynastie, dopiero wtedy zrozumiemy tę niezwykle ciekawą, a jakże indywidualną muzykę. Każda z dynastii wykształciła coś nowego, przyczyniając się do rozwoju kultury muzycznej Chin.

W okresie panowania Zachodniej Dynastii Zhou (1122-772 p.n.e.) znano już dwanaście podstawowych tonów (dwunastotonowa skala chromatyczna), porównywalnych z dwunastoma półtonami muzyki zachodniej, a także pięć podstawowych tonów (chińska pentatonika), porównywanych z pięcioma pełnymi tonami muzyki zachodniej. Do tego doszły dwa tony pośredniczące, tak zwane tony zmienione (bianzhi) lub pieny (biangong) ${ }^{9}$. Gama penta-

\footnotetext{
${ }^{7}$ Ibid., s. 144.

${ }^{8}$ Ibid., s. 143.

${ }^{9}$ Anna CzeKanowska, Kultury muzyczne Azji, Kraków: Polskie Wydawnictwo Muzyczne 1981, s. 23.
} 
toniczna (pięciotonowa) była najstarsza, $\mathrm{z}$ czasem dodano do niej jeszcze dwa półtony, tworząc kolejną, siedmiotonową (heptatoniczną). Nie była ona jednak tak popularna jak pentatoniczna. Skala pentatoniczna (do-re-mi-solla) jest charakterystyczna dla wielu dawnych kultur. W Chinach jej genezę wywodzono niekiedy z dwóch szeregów piszczałek, wydających właściwe dźwięki. Pentatonika była silnie osadzona w systemie filozoficznym i kulturowym dawnych Chin, co zadecydowało o jej trwałym związku z kulturą muzyczną tego kraju. Właśnie tutaj, pomimo popularności również w innych częściach świata, przetrwała tysiąclecia w swojej pierwotnej formie. Ta zadziwiająca wierność pentatonice stała się też cechą charakterystyczną muzyki chińskiej.

Muzykę okresu dynastii Han charakteryzowało przenikanie elementów obcych, napływowych, zwłaszcza z zachodu oraz południa. Dla tego czasu typowy był rozwój aparatu wykonawczego, bogatej skali materiałowej, obejmującej 60 tonacji użytkowych, a dzieki temu znaczne rozszerzenie możliwości modulacyjnych. Za panowania tej dynastii pojawił się system zapisu dźwięków, chociaż przykłady znane są z czasów znacznie późniejszych. Rolę nut pełniły ideogramy, oznaczające lokalizację dźwięku w skali. Forma ta przetrwała aż do XX wieku, do momentu rozpowszechnienia się standardowego zapisu nutowego, takiego jak w Europie.

Ważnym wydarzeniem było utworzenie w II wieku p.n.e. przez cesarza Wu Cesarskiego Biura Muzyki, odpowiedzialnego za wszystko to, co wiązało się z tworzeniem, wykonywaniem i odbiorem muzyki. Miało ono za zadanie zbieranie i gromadzenie melodii i tekstów pieśni ludowych z różnych regionów kraju.

Muzyka cieszyła się dużym zainteresowaniem władców, dlatego tak istotne stało się dla nich kształcenie muzyczne, zwłaszcza muzyków dworskich, którzy uczestniczyli w różnego rodzaju uroczystościch państwowych. Przygotowywała ich Cesarska Akademia Muzyki, zwana „Ogrodem grusz”, która miała także sekcję żeńską zwaną „Ogrodem wiecznej wiosny”. Zespoły cesarskie składały się z wielkiej liczby muzyków, przede wszystkim instrumentalistów. Orkiestra dworska liczyła wówczas 800 muzyków. Dynastia Han miała aż trzy orkiestry, składające się w sumie z 829 muzyków. Ówczesne utwory muzyczne to melodie grane na instrumentach dętych i perkusyjnych z okazji procesji, oficjalnych uroczystości cywilnych oraz melodie xiangge, czyli cieszące się uznaniem pieśni ludowe. Zespoły muzyczne istniały nie tylko na dworze cesarskim, chęć ich posiadania była powszechna 
wśród możnych, a wielkość zespołu dawała wyobrażenie o randze społecznej właściciela, jego bogactwie i władzy ${ }^{10}$.

Za panowania dynastii Wei (220-265 p.n.e) w melodiach wyróżniono trzy skale. Pierwsza $\mathrm{z}$ nich zastąpiła tonikę jiao toniką sediao, druga tonikę shang - qingdiao, natomiast trzecia tonikę gong - pingdiao. Z czasem określenie qingshang, które pierwotnie oznaczało konkretną skalę, nabrało większego znaczenia i zaczęło oznaczać wszystkie trzy skale. Biuro Muzyki (qingshangshu), zbierające melodie popularne zarówno na północy, jak i na południu, po pewnym czasie stało się nazwą ogólną całej tradycyjnej muzyki chińskiej, kwitnącej za czasów dynastii Han i Wei, zanim zaznaczyły się wpływy muzyki z Azji Śrokowej za rządów dynastii Tang ${ }^{11}$.

W okresie rządów dynastii Tang występowały dwa rodzaje muzyki. Pierwszy rodzaj obejmował wielkie melodie, mające swoją gradację i skomplikowaną strukturę, które grane były przede wszystkim na dworze cesarskim. Drugi rodzaj to różne melodie (zagui) o charakterze popularnym. W muzyce dworskiej rozróżniano „muzykę na siedząco”, graną przez muzyków na estradzie, oraz „muzykę na stojąco”, graną do tańca przez muzyków, którzy stali z tyłu lub po bokach sceny ${ }^{12}$.

Za panowania tej dynastii nastąpił wyraźny wzrost wpływów południowych oraz większy rozwój orkiesty dworskiej. Powstało wówczas kilka odmian orkiestry w zależności od stylu, przeznaczenia, pojawiły się również jej odmiany regionalne. Na początku okresu istniało siedem odmian orkiestr, a z czasem ich liczba wzrosła do dziewięciu. Muzyka w tym czasie była silnie związana $z$ tańcem i pantomimą, a także stale z kultem przodków. Dawne podziały z okresu klasycznego, dotyczące sporu między muzyką rodzimą i obcą oraz kultową i dworską a użytkową, zaczęły się zacierać. Skala materiałowa została rozszerzona do 84 stopni, ale używano zaledwie 28 spośród nich.

Znaczny rozwój zaznaczył się w dziedzinie muzyki świeckiej, związanej ze Świętem Wiosny. Rozwinęły się takie jej gatunki, jak pieśń liryczna i muzyka dramatyczna, której szczególny rozwój przypadł na okresy późniejsze. Cesarz Xuanzong założył na swoim dworze i w stolicy konserwatoria muzyczne (jiaofang), których zadaniem było gromadzenie, nauczanie

\footnotetext{
${ }^{10}$ SZLAGOWSKA, Kultura muzyczna antyku, s. 19.

${ }^{11}$ Jacques Pimpaneau, Chiny. Kultura $i$ tradycje, przeł. Irena KaŁuŻyńsKa, Warszawa: Wydawnictwo Akademickie Dialog, 2001, s. 224.

${ }^{12}$ Ibid.
} 
i upowszechnianie utworów muzycznych i tańców. Najsłynniejszym muzykiem epoki Tang był Li Guinian.

Za czasów dynastii Tang wyraźnie się wyodrębniły i rozwinęły równolegle dwa nurty muzyczne - religijny i świecki. Przyjęła się również notacja tabulaturowa, która zastąpiła notację wcześniejszą. Określała ona precyzyjne ułożenie palców i typy zarywania, różnicowała chwyty prawej i lewej ręki. Notacja ta była używana jeszcze w epoce Ming, a we fragmentach nawet do początków XX wieku.

Muzyka za czasów dynastii Song wiązała się ściśle ze śpiewanymi na wiele sposobów balladami oraz z operą, gdzie jeden ciąg tworzyły całości melodyczne o tej samej skali (taoshu). W okresie najazdów koczowników stepowych na południe Chin muzyka uległa silnej diatonizacji. Można również wnioskować o rozwoju w tym czasie gry wirtuozowskiej, zwłaszcza na instrumentach lutniowych, których tradycje sięgają starożytności. Wówczas też wykształciły się podstawowe założenia teorii modalnej, a zwłaszcza przepisy dotyczące finalis i dźwięku centralnego. Teoria ta, zwłaszcza w odniesieniu do muzyki na cytrę, rozwijała się przez następne wieki, dochodząc do rozkwitu w okresie dynastii Ming.

Jeżeli chodzi o rozwój notacji, od panowania dynastii Song nuty zapisywano prostszymi znakami, natomiast w XIII wieku wprowadzono gamę heptatoniczną, porównywalną z zachodnią gamą diatoniczną.

Sześć wysokości podstawowych (liulü) określano za pomocą tub bambusowych, wydających dźwięki o odpowiedniej wysokości. W praktyce używano dwunastu tub bambusowych o różnej długości, wydających dźwięk o konkretnej wysokości i wyznaczających dwanaście wysokości podstawowych (liu). Każdy z tych dźwięków ma swoją nazwę. Przedstawiamy je uszeregowane od wysokości najniższych do najwyższych ${ }^{13}$.

$\begin{array}{llllll}1 & 2 & 3 & 4 & 5 & 6\end{array}$

huangzhong dalü taicu jiazhong guxian zhonglü

$\begin{array}{cccccc}7 & 8 & 9 & 10 & 11 & 12 \\ \text { ruibin } & \text { linzhong yize } & \text { manlü } & \text { wuyi } & \text { yingzhong }\end{array}$

Dwanaście wysokości podstawowych dzielono na dwie grupy: yin i yang. Wysokości yang były nieparzyste, natomiast yin parzyste.

${ }^{13}$ Ibid. 
W okresie dynastii Yuan, a następnie Ming nastąpił pełny rokwit muzyki dramatycznej, spadkobierczyni dawnych kultowych przedstawień pantomimicznych oraz liryki wokalnej. Od czasów dynastii Ming zaczęły się wykształcać różne style muzyki dramatycznej, początkowo zróżnicowane regionalnie. Dużą popularność zdobyły w tym okresie skrzypce erhu. Coraz bardziej rozwijała się muzyka rozrywkowa, związana ze świętem wiosny, wykazująca najpierw wpływy południowo-zachodnie, a następnie japońskie. Powstał nowy typ liryki z towarzyszeniem nowych instrumentów szarpanych (gitar księżycowych) ${ }^{14}$.

W XVIII wieku zaczęły się ukazywać coraz liczniejsze podręczniki gry na instrumentach strunowych, głównie na cytrze, omawiające nie tylko technikę gry, ale i zasadę budowy instrumentów, ich konserwacji, a przede wszystkim sposoby nawiązywania kontaktu ze słuchaczem poprzez wywołanie określonych nastrojów. Te zasady zostały podporządkowane obowiązującym normom estetycznym.

Ogólną cechą kultury muzycznej okresu Ming był jednak powrót do tradycji klasycznych sprzed najazdu Mongołów. Dotyczyło to w pierwszej kolejności systemu tonalnego - pentatoniki. Dopiero pod koniec rządów dynastii Ming przyjęto powszechną tonację C-dur i zasady temperacji. Chcąc lepiej zrozumieć teorię chińską, musimy uwzględnić obowiązujące normy estetyczno-kulturowe. U ich podstaw tkwią wyobrażenia wierzeniowe, przenoszone następnie na pojęcia symboliczne i kojarzone $\mathrm{z}$ określonymi nastrojami.

Jedną z najistotniejszych cech muzyki chińskiej jest pentatonizm, który określa zwroty melodyczne oraz interwałowe. Bardzo ważna jest dominacja sekund i tercji oraz sekund i kwarty. Pentatonizm stanowi również o specyfice wyrazowej muzyki chińskiej. Mimo że skalę tę spotyka się w wielu kulturach, nie tyle więc jej występowanie, ile wyjątkowe rozpowszechnienie i dominacja, utrzymująca się w zasadzie do dziś, jest cechą specyficznie chińską. Kolejną istotną cechą jest dominacja słowa nad melodią. Recytatyw jest formą zasadniczą liryki wokalnej, dominuje również w muzyce dramatycznej. Jeżeli chodzi o rytmikę, w muzyce chińskiej zaznacza się metrum dwumiarowe, ale spotkać możemy również metrum trójmiarowe ${ }^{15}$.

Dla muzyki dramatycznej typowy jest związek z tańcem oraz zasada alternacji partii deklamowanych z towarzyszeniem instrumentów i wyłącznie

\footnotetext{
${ }^{14}$ CzeKanowsKa, Kultury muzyczne Azji, s. 25.

${ }^{15}$ Ibid., s. 34.
} 
instrumentalnych. Bardzo rozbudowany jest aparat wykonawczy. Cechą niespotykaną $\mathrm{w}$ innych kulturach są niektóre stroje (w dawnej muzyce uzależnione od pór roku) oraz barwy, pozostające w związku z dawnymi nakazami kultowymi, precyzującymi rodzaj materiału używanego do budowy instrumentów.

Wielogłosowość ograniczona jest do swoich prymitywnych przejawów: organum, burdonu, heterofonii, pierwotnego kanonu. W muzyce nowszej wielogłosowość jest zjawiskiem niezwykle rzadkim. Dynamizm i agogika służą do wyodrębnienia poszczególnych części utworów. Szczególnego znaczenia nabierają niektóre maniery wykonawcze, wykorzystujące efekty ilustracyjne i określające stany emocjonalne. Charakterystyczną cechą jest również specyficzne szkolenie głosu, umożliwiające uzyskiwanie różnorodnych efektów przez operowanie odmiennymi rejestrami.

Ta niezwykle charakterystyczna muzyka odgrywa wielką rolę w życiu społeczności chińskiej, przez co nadaje temu regionowi jedyny, niepowtarzalny rys. Mimo że wpływ Zachodu zaznaczył się na muzycznym rozwoju tego kraju, to i tak zachował on swoją tradycyjną tożsamość i indywidualny charakter.

Kolejną rzeczą niezmiernie ważną dla rozwoju kultury muzycznej Chin, było wytworzenie na przełomie epok różnych gatunków muzycznych. W chińskiej muzyce tradycyjnej możemy wyróżnić muzykę kultową, dworską, lirykę wokalną oraz aktualną do dnia dzisiejszego muzykę dramatyczą, kameralną i ludową ${ }^{16}$.

Tak muzyka kultowa, jak i dworska miały charakter wokalny, z tym że czasami wykonywana była z towarzyszeniem instrumentów. Owa muzyka prezentowana była w świątyniach i ogrodach. Niejednokrotnie łączyły się $\mathrm{z}$ nią tańce. Uroczystości wiązały się $\mathrm{z}$ ważnymi wydarzeniami państwowymi, z epizodami z życia rodziny cesarskiej, z kultem przodków i narodzinami potomstwa. Kultywowana była muzyka buddyjska, natomiast na dworze wykonywano również tzw. muzykę wytworną, związaną z uroczystościami dworskimi i paradami wojskowymi.

Innym gatunkiem jest liryka wokalna, która wiązała się z muzyką kultową i dramatyczną. Jej widoczny rozwój możemy śledzić od IV wieku n.e. Zasadniczą popularnością cieszyła się forma $c i$ (pieśń), udokumentowana przez liczne przekazy nutowe od XVIII wieku ${ }^{17}$. Cechą charakterystyczną

\footnotetext{
${ }^{16}$ Pimpaneau, Chiny. Kultura i tradycje, s. 223.

${ }^{17}$ CzeKanowsKa, Kultury muzyczne Azji, s. 43.
} 
dla formy $c i$ jest pentatonika, melodyka deklamacyjna i stosowanie ozdobników. Przekazy tej formy zostały zapisane w postaci notacji neumatycznej.

Muzyka dramatyczna, zwana operą, ukształtowała się z trzech elementów: tańców kultowych, liryki wokalnej i mongolskiej pantomimy. Początkami sięga czasów dynasii Han, właściwa muzyka dramatyczna jednak popularność swą zaczęła uzyskiwać dopiero w początkach XVIII wieku. Istniało kilka stylów tej formy, zróżnicowanych regionalnie i historycznie.

Jednym z tych stylów jest Quangzhou, zwany klasycznym, który jest spadkobiercą południowej muzyki dramatycznej. Innymi natomiast są Erhuang (XVII wiek) oraz Xibi, które przetrwały we fragmentach do naszych czasów ${ }^{18}$.

Charakterystyczną sprawą dla muzyki dramatycznej jest długotrwały okres prezentacji, przy czym partie wokalne w są raczej w specyficzny sposób deklamowane niż śpiewane. W recytacji zasadniczą cechą jest zwiększenie interwałów. Między partiami deklamowanymi przeplatają się partie instrumentalne, tj. wirtuozowskie interludia melodyczne (flet i skrzypce), oraz odcinki, w których wielką rolę odgrywają idiofony.

Nowsza muzyka dramtyczna charakteryzuje się większą dominacją słowa, a rolę pierwszoplanową odgrywają wielkie gongi. Zestaw instrumentów typowy dla tego gatunku to flet lub skrzypce oraz cztery grupy perkusji: kołatki drewniane, niecki metalowe, bęben i wielki gong. Treścią dramatów są najczęściej intrygi złych sił, czyhanie, podstępy.

Jeżeli chodzi o muzykę kameralną, to rozwinęła się ona dzięki rozpowszechnieniu instrumentów strunowych szarpanych, m.in. cytry i lutni. W dawnych tradycjach muzyka ta miała charakter improwizacyjny. Jest ona zazwyczaj jednogłosowa i stosuje się w niej dużo modulacji.

Na temat pieśni ludowej obecnie niewiele wiemy, jedynie tyle, że ma ona charakter zachowawczy, często znamionuje ją skala pentatoniczna, elementy wielogłosowości oraz miarowa rytmika. Twórczość ta obejmuje takie gatunki, jak pieśni pracy oraz pieśni weselne. Dużą rolę odgrywają różnego rodzaju zawołania oraz pieśni na dzień urodzin, związane z kultem nieśmiertelności i symbolem wiecznego odradzania.

Symbole muzyczne i rysunki, króre zapisane zostały na skorupach żółwi, są bezpośrednim źródłem poznania notacji muzycznej, która zaliczana jest do najstarszych świadectw istnienia starożytnej kultury muzycznej Chin.

\footnotetext{
${ }^{18}$ Krzysztof Biegański [i in.], Mata encyklopedia muzyki, Warszawa: PWN, 1981, s. 164.
} 
W epoce Zhou, a w szczególności za panowania dynastii Han rozwinął się system solmizacyjnych oznaczeń dla lü, o czym już wspominano. Odszyfrowany został system notacyjny stosowany w VII wieku n.e., który składał się z zespołu wskazówek dla dyrygenta ${ }^{19}$. Owe wskazówki mówiły, kiedy rozpocząć, uderzyć, skrócić, powtórzyć kilka razy bądź skończyć zwrotkę, a także zakończyć cały utwór. Towarzyszył temu zapis kolejnych wysokości dźwięków, przy czym niektóre z nich były zróżnicowane według oktaw. Dźwięki wypełniały cały takt, natomiast głosy lub instrumenty towarzyszące ozdabiały dźwięk podstawowy według wskazówek dyrygenta. Czas trwania wciąż pozostawał nieokreślony.

W XII wieku stosowano już znaki określające dewiację (znak ,,+" nad dźwiękiem oznaczał podwyższenie, natomiast znak „,-" obniżenie) podstawowych dźwięków ${ }^{20}$. Zawiłe oznaczenia stosowano dla bienów, które były w użyciu już od czasów starożytnych. Dopiero za panowania dynstii Ming znaki te uproszczono. Obecnie widoczna jest duża różnica między interwałami śpiewanymi a mówionymi.

Oprócz systemu lü rozwinęła się w Chinach notacja tabulaturowa na cytrę i lutnię. Notacja przeznaczona na cytrę qin, którą posługiwano się w starożytności, została opisana wyczerpująco w podręcznikach z epoki Ming, które stanowią podstawę wiedzy na temat teorii o muzyce chińskiej.

Tabulaturowa notacja o charakterze cyfrowym precyzyjnie rejestrowała chwyty prawej i lewej ręki. Typy zarywań i skracania strun oraz pozycje oznaczane były numerycznie, np. 1 - to oznaczało naciśnięcie struny kciukiem i natychmiastowe zwolnienie jej bez dotchnięcia następnej, $2-p i$ pociągnięcie struny paznokciem kciuka, co w rezultacie dawało dźwięk bardzo jasny. Występowały także określenia złożone, które należy rozumieć jako zastosowanie dwóch różnych technik. Dochodziły do nich pauzy, które w konsekwencji kształtowały określone modele rytmiczne. Notacja ta miała szereg oznaczeń, wśród których nie brak było wskazówek wykonawczych, m.in. artykulacyjnych czy agogicznych.

System notacji kungche na pipę, podobnie jak sam instrument i utwory na niego przeznaczone, np. słynna lamentacja Zhao-Chun, również wywodzą się ze starożytności ${ }^{21}$. Ów system, stosowany po dzień dzisiejszy, rozwinął się dopiero w końcowym okresie epoki Tang i Song.

\footnotetext{
${ }^{19}$ Ibid., s. 163

${ }^{20}$ CzeKanowska, Kultury muzyczne Azji, s. 35.

${ }^{21}$ Provine, Tokumaru, Witzleben (eds), Garland Encyclopedia of World Music, vol. 7, s. 169.
} 
Okres szczególnego rozwoju przypadł na wieki XIII i XIV, kiedy muzyka na pipę była bardzo ceniona. Istnieją dwie wersje tej notacji: północna, obejmująca prawie trzyoktawowy zakres dźwięków, i południowa (Kanton), utwalająca dźwięki w przedziale $\mathrm{G}-\mathrm{d}^{22}$. Skala materiałowa miała charakter chromatyczny. W wersjach tej notacji wysokość znaczono cyframi zgrupowanymi w rzędy. Po prawej stronie były kolumny znaków określających długość trwania dźwięków i szczegóły wykonawcze. Dźwięki podstawowe o standardowej długości nie miały żadnych oznaczeń.

Bardzo istotną rolę, zwłaszcza w praktyce, odgrywały podstawowe teksty słowne. Wykonywne były szeptem, a określone zwroty, słowa i sylaby wiersza informowały o rodzajach chwytów zakodowanych liniowo. Niektóre elementy tej notacji używane były jeszcze po II wojnie światowej, gdy cytra była wciąż instrumentem bardzo popularnym.

Większość publikacji poświęconych grze na cytrze pochodzi z lat dwudziestych i trzydziestych XX wieku. Zasadniczą rzeczą jest korelacja ruchów (chwytów) grającego $\mathrm{z}$ tekstem, np. na początku słowa musiał zawsze przypadać atak prawej ręki lub zwolnienie lewej. Na jedną sylabę przypadał zazwyczaj jeden chwyt, słowa rzadko były przedłużane przez melizmaty, które nie mogły trwać dłużej aniżeli dwa chwyty. Teksty o szczególnej popularności miały w większości tytuły programowe i symboliczne, takie jak np. „Śpiew nieograniczonej radości” czy „Śpiew jesiennego wiatru”. Symbolika i ilustracyjność miały w Chinach duże znaczenie, mimo że dla nas są bardzo trudne do odczytania. Teoria muzyki, jak widzimy, charakteryzuje się pewną indywidualnością, dzięki czemu tradycyjna muzyka chińska miała swój własny i odrębny system notacji, który dopiero w momencie zetknięcia się z kulturą europejską zaczął się zmieniać. Tak samo było z teorią, gatunkami oraz instrumentarium. Widoczne to jest już w XVII wieku, lecz znaczące zmiany $\mathrm{w}$ tej dziedzinie przyniósł dopiero wiek XX. Decydujący wpływ miała rewolucja burżuazyjna i związane z nią przeobrażenia kulturalne, które zadecydowały o odejściu od form najbardziej archaicznych w muzyce chińskiej. Wskutek tego wyszło z użycia większość dawnych instrumentów, które zostały zastąpione nowymi, pochodzenia europejskiego, w szczególności fortepianem, akordeonem czy trąbką.

Od 1912 r. coraz intensywniej zaznacza się wpływ muzyki zachodnioeuropejskiej. Podczas widowisk, na których dotychczas była przedstawiana rodzima muzyka dramatyczna, wystawiany jest repertuar obcy. Ten nowy

${ }^{22}$ CzeKanowsKa, Kultury muzyczne Azji, s. 42. 
typ muzyki dramatycznej otrzymał nazwę opery, w odróżnieniu od muzyki tradycyjnej, nazywanej konsekwentnie dramatyczną.

W związku z tym wykształciły się nowe nurty: muzyki rodzimej i muzyki obcej, z tym że pod pojęciem muzyki obcej pojmowano nie muzykę krajów azjatyckich sąsiadujących z Chinami, tylko muzykę zachodnioeuropejską.

Pierwszy kontakt z muzyką europejską, był momentem przełomowym w rozwoju kultury muzycznej Chin. Pozwolił on na odejście od archaicznych form oraz dawnych rygorystycznych norm i zakazów. Po 1912 r., kiedy zaszły radykalne zmiany $\mathrm{w}$ tej dziedzinie, wpływ muzyki europejskiej znacznie wzrósł. Podjęto próby wypracowania nowego stylu, asymilującego zdobycze muzyki europejskiej, lecz nawiązującego do tradycji chińskich. Wpływ Zachodu pozwolił na powiększenie się liczby gatunków muzycznych, rozpowszechniły się dzięki temu formy wokalno-instrumentalne znajdujące szeroki odzew społeczny, takie jak opera, oratorium czy kantata. Zaczęto uprawiać muzykę programową i ilustracyjną nawiązującą do folkloru.

Chińskie elity intelektualne zaczęły poznawać i uczyć się muzyki zachodniej od przybyłych do Kraju Środka żydowskich i rosyjskich muzyków emigracyjnych. Tak pojawili się pierwsi kompozytorzy chińscy. Zaznaczyć bowiem trzeba, że dotychczas idea indywidualnej twórczości nie była w Chinach znana. Do orkiestr wprowadzono nowe instrumenty, przy czym instrumentem bardzo cenionym zarówno przez mieszczaństwo, jak i inteligencję stał się fortepian.

Ciężkie czasy dla muzyki chińskiej nastały w 1937 r. po wybuchu wojny chińsko-japońskiej. Artyści starali się podtrzymywać życie muzyczne w kraju. Wielu muzyków musiało jednak porzucić swoje dotychczasowe zajęcia i wziąć udział w walce z japońskim okupantem. Sytuacja wojenna wymogła kilkakrotne przenosiny Konserwatorium Muzycznego. Głównym organizatorem życia muzycznego był w tym czasie He Luting, który w 1940 r. założył pierwszą złożoną z samych Chińczyków zawodową orkiestrę symfoniczną, której dyrygentem został skrzypek Ma Sicong ${ }^{23}$. W repertuarze tej orkiestry oprócz dzieł znanych zachodnich kompozytorów, Beethovena, Mendelssohna czy Musorgskiego, były się również kompozycje chińskie. Ogromną rolę odegrał Włoch Mario Piaci, który objął kierownictwo orkiestry. Upowszechnił on i spopularyzował muzykę zachodnią w Chinach.

${ }^{23}$ Krzysztof Kwiatkowski, Duch cele i środki. Asymilacja muzyki zachodniej w Chinach, http://www.ruchmuzyczny.pl/PelnyArtykul.php?Id=454 (dostęp: 31.08 .2010 ). 
W latach trzydziestych XX wieku powstałą baza ruchu komunistycznego w Yan'an. Obszar ten - tak ubogi, że przywódcy partyjni mieszkali w jaskiniach - ściągał licznych wykształconych idealistów, w tym najwybitniejszych muzyków. Taniec, teatr oraz muzyka były uważane przez komunistów za potężne narzędzia walki.

W Yan'anie powstała Akademia Sztuki i Literatury im. Lu Xuna, której zadaniem było kształecenie kadr partyjnych w zakresie sztuki, literatury i muzyki. Wykładowcami byli wybitni specjaliści, którzy wywodzili się z chińskich elit intelektualnych. Starali się oni zapoznać studentów z najwybitniejszymi osiągnięciami sztuki światowej i cennymi elemenatmi rodzimej tradycji. Niektórzy intelektualiści sprzeciwali się przywiązywaniu nadmiernej wagi do jakości artystycznej. W tej sprawie wypowiedział się także Mao Zedong, którego zdanie było zawsze punktem odniesienia w chińskich sporach i decyzjach dotyczących sztuki. Mao Zedong w swoich wywodach, które były skierowane przeciwko intelektualistom, stwierdził, że nie rozumieją oni, iż nie istnieje sztuka sama dla siebie - sztuka jest zawsze dla kogoś.

Działacze kulturalni oraz muzycy w Yan'anie podzielili się na dwa obozy. Do pierwszego należeli ci, którzy zalecali przede wszystkim łączenie rewolucyjnych treści z formami chińskiej muzyki ludowej oraz krytykowali poczynania twórców wykorzystujących bardziej złożone formy zachodniej muzyki. Drugi obóz głosił konieczność przystosowania zachodniej muzyki artystycznej do potrzeb rewolucji oraz podnoszenia kuluralnego poziomu mas społecznych. Do zwolennuków takiej wizji należał Xian Xinghai, który w Yan'anie m.in skomponował operę Marsz armii i ludu z uwerturą, ariami i recytatywami, a instrumentarium składało się zarówno $\mathrm{z}$ instrumentów europejskich, jak i chińskich ${ }^{24}$.

W skład centralnej orkiestry weszli nie tylko znani i wyształceni muzycy, ale także chłopi, których nauczono gry od podstaw na instrumentach. Postanowiono, że orkiestra będzie się uczyć i od razu pokazywać, czego nowego się nauczyła. Aby tę inicjatywę sprawdzić, odbył się pierwszy koncert, na którym wykonano proste opracowanie menueta Bacha i trzy łatwe utwory $\mathrm{He}$ Lutinga. Do obowiązków orkiestry należało także przygrywanie do sobotnich tańców, w których z chęcią brali udział komunistyczni przywódcy.

W styczniu 1948 r. Komunistyczna Partia Chin zarządziła wycofanie się z Yan'anu, spodziewając się ataku. Muzycy z instrumentami na plecach postanowili ruszyć pieszo, dając po drodze koncerty dla chłopów parcelujących

${ }^{24}$ Ibid. 
ziemię w ramach reformy rolnej. Często przyjmowani byli bardzo ciepło, chcąc więc odwdzięczyć się za gościnę, zatrzymywali się danym miejscu na dłużej i wykonywali cały swój repertuar. Dzięki temu chłopi mogli poznać i usłyszeć Serenadę Mozarta czy Marsz wojskowy Schuberta. Wreszcie orkiestra dotarła do Pekinu.

Po 1949 r. coraz bardziej popularna zaczęła się stawać w Chinach muzyka Chopina. Rząd Chińskiej Republiki Ludowej żarliwie chciał udowodnić, że może konkurować z Zachodem. Młodym muzykom chińskim zezwolono na udział w międzynarodowych konkursach muzycznych. W 1955 r. młody pianista chiński Fu Cong zajął trzecie miejsce na Konkursie Chopinowskim $^{25}$.

Pod koniec lat pięćdziesiątych powstały kolejne konserwatoria, m.in. w Shenyangu i Chengdu. W wielu miastach działały orkiestry symfoniczne, zespoły baletowe oraz inne profesjonalne orkiestry, takie jak np. Orkiestra Robotników Zakładów Urządzeń Elektrycznych i Automatycznych w Pekinie. Zaczęto wystawiać nie tylko chińskie opery tradycyjne, ale również opery nowoczesne, które zasadniczo różniły się od tradycyjnych chińskich, a nawet europejskich form operowych.

W tamtym czasie wielką rolę odegrali rosyjscy instruktorzy chórów, orkiestr i zespołów operowych. Tradycyjna muzyka chińska uprawiana była nadal w teatrze ( $w$ dawny sposób, czyli w ramach wielogodzinnych przedstawień), jak też w szkołach i domach kultury.

W 1966 r. rozpoczęła się w Chinach tak zwana rewolucja kulturalna. W tym okresie wszelkie formy sztuki związane z kulturą Zachodu zostały przez rząd zabronione. Zamknięto wszelkie instytucje, w których uczono muzyki zachodniej, oraz ministerstwo kultury. Wszystko, co wiązało się z Zachodem, zostało usunięte, a jakakolwiek próba zmiany tego stanu rzeczy była surowo karana. Wszystkie fortepiany zostały bądź zniszczone, bądź w najlepszym razie schowane. Narastała wrogość wobec cudzoziemców, którą wzmacniała atmosfera zimnej wojny. Wykonywanie utworów kompozytorów zachodnich zostało zakazane.

Zmieniło się to dopiero po 1978 r. Spośród różnych kompozytorów zachodnich Chińczycy pokochali znowu Fryderyka Chopina. Jego muzyka była ceniona bardzo wysoko ze względu na jej narodowy charakter. Romantyczna i patriotyczna w swym wyrazie zdobyła serca Chińczyków do tego stopnia, że do dnia dzisiejszego jest uznawany za jednego z najwybitniejszych

\footnotetext{
${ }^{25}$ Ibid.
} 
kompozytorów. W dowód uznania wzniesiono mu pomnik w Szanghaju, nader rzadki w Chinach przypadek czci dla cudzoziemca.

Po rewolucji kulturalnej, która zakończyła się wraz ze śmiercią Mao Zedonga w 1976 r., muzyka, jak i sztuka powróciły do status quo ante, pomimo gigantycznych strat i ogólnego obniżenia poziomu kultury. Wielu zagranicznych muzyków próbowało nadal, mimo przeszkód, rozwijać życie muzyczne. Zelżały również napięcia między Chinami a Zachodem. Władze znów szczyciły się rozwojem kultury swojego kraju, wysyłając artystów za granicę i zapraszając zagranicznych wykonawców do Chin. Kompozytorzy odzyskali swobodę komponowania, a muzyka zachodnia znów zaczęła rozbrzmiewać w Kraju Środka.

Podsumowując, podkreślmy jeszcze raz, że muzyka chińska zachowuje wciąż swój indywidualny charakter, pomimo że zaznaczył się w niej wpływ Zachodu. Mamy tu do czynienia z bardzo odmienną od europejskiej kulturą muzyczną, zwłaszcza w jej starożytnym okresie rozwoju.

W Chinach od najdawniejszych czasów muzyka odgrywała wielką rolę, była ściśle powiązana $z$ filozofią i religią. Wiara w społeczne i wychowawcze odziaływanie muzyki przyczyniła się do otoczenia jej wręcz kultem. Typowe ograniczenia, kultywowanie tylko pewnych gatunków, sposobów opracowania, instrumentów oraz jej rygorystyczny konserwatyzm i archaizm uczynił tą muzykę wyjątkową i jedyną w swoim rodzaju. Dla starożytnej kultury chińskiej muzyka stała się mądrością serca, która była i nadal jest nieodłączną częścią codziennego życia każdego Chińczyka.

\section{BIBLIOGRAFIA}

BIEGAŃSKI, KRZySzTOF [i in.]. Mała encyklopedia muzyki. Warszawa: PWN, 1981.

Clements, Jonathan. Konfucjusz - biografia, przeł. Agata MazursKa. Warszawa: Instytut Wydawniczy Erica, 2007.

CzeKanowsKa, Anna. Kultury muzyczne Azji. Kraków: Polskie Wydawnictwo Muzyczne 1981.

CZyŻewska-Madajewicz, Krystyna - KÜNSTler, MieCZysŁaw - TŁumski, ZdzisŁaw. Dialogi konfucjańskie. Wrocław: Zakład Narodowy im. Ossolińskich, 1976.

Eberhard, Wolfram. Symbole chińskie. Stownik. Obrazkowy język Chińczyków, tł. RenAtA DARDA. Kraków: TAiWPN UNIVERSITAS, 2001.

Fairbank, John King. Historia Chin. Nowe spojrzenie, przeł. Teresa LechowsKa, ZBigniew SŁUPSKI. Gdańsk: Wydawnictwo Marabut, 1996.

Fitzgerald, Charles Patrick. Chiny. Zarys historii kultury, przeł. AleKsander Bogdański. Warszawa: PIW, 1974.

Granet, Marcel. Cywilizacja chińska, przeł. MieczysŁaw Künstler. Warszawa: PIW, 1973. 
Keim, Jean Alphonse. Sztuka chińska. 1: Od początków do dynastii T'ang; 2: Pięć dynastii i pótnocna dynastia Sung; 3: Poludniowa dynastia Sung i Jüan; 4: Dynastie Ming i Ts'ing, przeł. Piotr Parandowski, red. wyd. pol. Grzegorz KiljańCzyK, Mała Encyklopedia Sztuki. Warszawa: Arkady, 1978.

Kossak, Steven M. [i in.] (ed.). The Art of South and Southeast Asia. New York, The Metropolitan Museum of Art, 2001.

Kowalska, MaŁgorzata. ABC historii muzyki. Kraków: Musica Jagellonica, 2001.

KÜnStler, MieczysŁaw. Dzieje kultury chińskiej. Warszawa: Wydawnictwo Naukowe PWN, 2007.

KünStler, MieczysŁaW. Mitologia chińska. Warszawa: Wydawnictwo Naukowe PWN, 2001.

KÜNSTler, MieCZYSŁaW. Sprawa Konfucjusza. Warszawa: Iskry, 1983.

KüNSTler, MieczysŁaw. Sztuka Chin. Warszawa: Wiedza Powszechna, 1991.

KwiatKowski, Krzysztof. Duch cele i środki. Asymilacja muzyki zachodniej w Chinach, http://www.ruchmuzyczny.pl/PelnyArtykul.php?Id=454 (dostęp: 31.08.2010).

Needham, Joseph. Science and civilisation in China. Cambridge: Cambridge University Press, 1954.

Olszewski, WiesŁaw. Chiny. Zarys kultury. Poznań: Wydawnictwo Naukowe Uniwersytetu im. Adama Mickiewicza, 2003.

Pimpaneau, Jacques. Chiny. Kultura i tradycje, przeł. Irena KaluŻyńsKa. Warszawa: Wydawnictwo Akademickie Dialog, 2001.

Prodan, Mario. Sztuka chińska, przeł. MieczysŁaw Künstler. Warszawa: PWN, 1975.

Provine, Robert C. - Tokumaru, Yosihiko - Witzleben, J. Lawrence (eds). Garland Encyclopedia of World Music, vol. 7: East Asia: China, Japan, and Korea. University of Maryland, 2001.

RODZIŃSKI, WiTOLD, Historia Chin. Wrocław: Zakład Narodowy im. Ossolińskich, 1992.

SACHS, CURT. Historia instrumentów muzycznych, przeł. STANISŁAW OlĘDZKI. Kraków: Polskie Wydawnictwo Muzyczne, 1989.

SCARPARI, MAURIZIO. Starożytne Chiny, przeł. P. KACZMARCZYK. Warszawa: Folio, 2008.

SHAUghnessy, EdWARD L. Chiny - kraj niebiańskiego smoka. Kultura, filozofia, religia, nauka, sztuka, architektura, dziedzictwo czterech tysięcy lat, przeł. ANNA MALESZKO, BożENA MiERZEJEWSKA. Warszawa: Horyzont, 2001

SŁawiŃSKa, Irena, Chińszczyzna. Toruń: wyd. Adam Marszałek, 2004.

SzlagowsKa, DanUta. Kultura muzyczna antyku. Gdańsk: Wydawnictwo Akademii Muzycznej im. Stanisława Moniuszki, 1983.

ŻBIKOWSKI, TADEUSZ. Konfucjusz. Warszawa: KiW, 1960.

ŻBIKOWSKI, TADEUSZ. Legendy i pradzieje Kraju Środka. Warszawa: Iskry, 1978.

\section{MUZYKA W KULTURZE CHIŃSKIEJ}

Streszczenie

Artykuł jest przeglądem historii muzyki chińskiej od czasów starożytnych do dziś. Autorka podkreśla, że muzyka chińska zachowuje wciąż swój indywidualny charakter, pomimo że zaznaczył się w niej wpływ Zachodu. W przypadku Chin mamy do czynienia z bardzo odmienną od europejskiej kulturą muzyczną, zwłaszcza w starożytnym okresie jej rozwoju.

W Chinach od najdawniejszych czasów muzyka odgrywała wielką rolę, była ściśle powiązana z filozofią i religią. Wiara w społeczne i wychowawcze odziaływanie muzyki przyczyniła się do otoczenia jej wręcz kultem. Typowe ograniczenia, kultywowanie tylko pewnych gatunków, spo- 
sobów opracowania, instrumentów oraz jej rygorystyczny konserwatyzm i archaizm uczynił tą muzykę wyjątkową i jedyną w swoim rodzaju. Dla starożytnej kultury chińskiej muzyka stała się mądrością serca, która była i nadal jest nieodłączną częścią codziennego życia każdego Chińczyka.

Słowa kluczowe: kultura chińska, muzyka chińska.

Key words: Chinese culture, Chinese music. 